\title{
Magnesium sulfate ameliorates carbon monoxide-induced cerebral injury in male rats
}

\author{
GHOLAMREZA BAGHERI ${ }^{1 *}$, RAMIN REZAEE $^{2 *}$, KONSTANTINOS TSAROUHAS $^{3}$, ANCA OANA DOCEA ${ }^{4}$, \\ JAFAR SHAHRAKI ${ }^{5,6}$, MALIHE SHAHRIARI $^{5,6}$, MARTIN F. WILKS $^{7}$, HOSSEINALI JAHANTIGH $^{8}$, \\ KAVEH TABRIZIAN $^{5,6}$, ALIREZA ABDOLLAHI MOGHADAM ${ }^{9}$, SOMAYEH BAGHERI ${ }^{10}$, \\ DEMETRIOS A. SPANDIDOS ${ }^{11}$, ARISTIDIS TSATSAKIS ${ }^{12}$ and MAHMOUD HASHEMZAEI ${ }^{5,6}$
}

${ }^{1}$ Department of Health, Zabol University of Medical Sciences, 9861615881 Zabol; ${ }^{2}$ Clinical Research Unit,

Faculty of Medicine, Mashhad University of Medical Sciences, 9177948564 Mashhad, Iran; ${ }^{3}$ Department of Cardiology,

University Hospital of Larissa, 41110 Larissa, Greece; ${ }^{4}$ Department of Toxicology, Faculty of Pharmacy,

University of Medicine and Pharmacy, 200349 Craiova, Romania; ${ }^{5}$ Department of Pharmacodynamics and Toxicology, and ${ }^{6}$ Students Research Committee, School of Pharmacy, Zabol University of Medical Sciences, 9861615881 Zabol, Iran;

${ }^{7}$ Swiss Centre for Applied Human Toxicology, University of Basel, CH-4055 Basel, Switzerland; ${ }^{8}$ Department of Pathology,

Amiralmomenin Hospital, Zabol University of Medical Sciences, 9861615881 Zabol; ${ }^{9}$ Department of Cardiology,

Emam Reza Educational Center, Mashhad University of Medical Sciences, 9137913316 Mashhad; ${ }^{10}$ Department of Biostatisics and Epidemiology, Faculty of Public Health, Zabol University of Medical Sciences, 9861615881 Zabol, Iran;

${ }^{11}$ Laboratory of Clinical Virology, and ${ }^{12}$ Department of Forensic Sciences and Toxicology,

Faculty of Medicine, University of Crete, 71003 Heraklion, Greece

Received October 2, 2018; Accepted December 5, 2018

DOI: $10.3892 / \mathrm{mmr} .2018 .9771$

\begin{abstract}
Carbon monoxide (CO) has been shown to induce several cardiovascular abnormalities, as well as necrosis, apoptosis and oxidative stress in the brain. Magnesium sulfate (MS) has been shown to have beneficial activities against hypoxia in the brain. In the present study, the possible protective effects of MS against CO-induced cerebral ischemia were investigated. For this purpose, 25 male Wistar rats were exposed to 3,000 ppm CO for $1 \mathrm{~h}$. The animals were divided into 5 groups ( $n=5$ in each group) as follows: The negative control group (not exposed to $\mathrm{CO}$ ), the positive control group ( $\mathrm{CO}$ exposed and treated with normal saline), and 3 groups of $\mathrm{CO}$-exposed rats
\end{abstract}

Correspondence to: Professor Aristidis Tsatsakis, Department of Forensic Sciences and Toxicology, Faculty of Medicine, University of Crete, Voutes, 71003 Heraklion, Greece

E-mail: aris@med.uoc.gr; tsatsaka@uoc.gr

Professor Mahmoud Hashemzaei, Department of Pharmacodynamics and Toxicology, School of Pharmacy, Zabol University of Medical Sciences, Shahid Rajaii Street, 9861615881 Zabol, Iran

E-mail: mhtoxicologist@gmail.com

${ }^{*}$ Co-first authorship

Key words: carbon monoxide poisoning, magnesium sulfate, cerebral ischemia, Akt, necrosis, apoptosis, $\mathrm{Bax} / \mathrm{Bcl} 2$ ratio, oxidative stress, malondialdehyde treated with MS (75, 150 and $300 \mathrm{mg} / \mathrm{kg} / \mathrm{day})$ administered intraperitoneally for 5 consecutive days. On the 5 th day, the animals were sacrificed and the brains were harvested for the evaluation of necrosis, apoptosis and oxidative stress. Histopathological evaluation revealed that MS reduced the number and intensity of necrotic insults. The $\mathrm{Bax} / \mathrm{Bcl} 2$ ratio and malondialdehyde (MDA) levels were significantly decreased in a dose-dependent manner in the MS-treated rats compared to the positive control group, while a significant dose-dependent increase in Akt expression, a pro-survival protein, was observed. In addition, MS administration reduced pro-apoptotic indice levels, ameliorated histological insults, favorably modulated oxidative status and increased Akt expression levels, indicating a possible neuroprotective effect in the case of $\mathrm{CO}$ poisoning. On the whole, the findings of this study indicate that MS may prove to be useful in protecting against $\mathrm{CO}$-induced cerebral injury.

\section{Introduction}

Carbon monoxide (CO) is a toxic gas produced by the incomplete combustion of fossil fuels $(1,2)$. It is a cause of significant morbidity and mortality worldwide with no specific antidote. Although both normobaric and hyperbaric oxygen are used as a common treatment, neurological sequelae are common in survivors of $\mathrm{CO}$ poisoning $(3,4)$. In the USA, CO poisoning accounts for 50,000 referrals to emergency departments and causes 334 deaths annually (5). In Iran, the improper use of gasoline and natural gas appliances cause a significant number of CO poisoning cases (6). Reports from different parts of Iran 
have shown that the mortality and morbidity rates were higher compared to other parts of the world (6). The majority of cases of $\mathrm{CO}$ poisoning occur in the colder months of the year due to the use of fossil fuels in heating appliances (7,8). Therefore, $\mathrm{CO}$ poisoning is regarded as one of the most challenging cases of poisoning in Iranian health system. The pathophysiology of $\mathrm{CO}$ poisoning centers on the production of carboxyhemoglobin, which reduces the oxyhemoglobin concentration and consequently diminishes tissue oxygen delivery $(9,10)$. Since CO affinity to hemoglobin is approximately 230-270-fold higher than that of $\mathrm{O}_{2}$ to hemoglobin, even at low $\mathrm{CO}$ concentrations, the carboxyhemoglobin concentration becomes sufficiently high to induce toxicity (9). The clinical manifestations of $\mathrm{CO}$ poisoning are non-specific (i.e., headaches, fatigue, confusion, nausea, dizziness, visual problems, chest pain, shortness of breath, loss of consciousness and seizures) and they are principally associated with the deleterious effects of normobaric on the brain and heart $(11,12)$.

Magnesium sulfate (MS) is used for the treatment of several conditions, including eclampsia, pre-eclampsia and the prevention of torsade de pointes (13). It has attracted the interest of scientists due to its protective properties against cerebral ischemia/reperfusion (I/R) (14-16), as it has been shown to reduce brain cell necrosis, apoptosis and oxidative stress levels (17-21). Moreover, MS is inexpensive, widely available, is simple to administer and lacks severe adverse drug reactions for common uses in the treatment of pre-eclampsia, eclampsia and torsade de pointes $(22,23)$.

B-cell lymphoma-2 (Bcl2) controls mitochondrial membrane permeability in order to impede apoptotic signal transduction, whereas $\mathrm{Bcl} 2$-associated-X protein (Bax), as a pro-apoptotic factor, disrupts mitochondrial membrane potential and induces caspase- 3 activation, leading to irreversible apoptosis (24). As shown by recent literature, the $\mathrm{Bax} / \mathrm{Bcl} 2$ ratio alone stands as an index of cell apoptosis or survival (25-28). In addition, in our previous studies using a model of $\mathrm{CO}$ poisoning, a clear connection between apoptosis and the $\mathrm{Bax} / \mathrm{Bcl} 2$ ratio was proven by TUNEL assay and caspase activity measurements (29). Moreover, Akt is regarded as a pro-survival factor $(30,31)$, whose activation induces phosphorylation at different sites. Activated Akt influences a number of factors involved in apoptosis, either by transcription regulation or direct phosphorylation, yielding favorable effects against ischemia-induced apoptosis. Thus, chemicals capable of inducing Akt expression/activity may be used in the treatment of I/R injury (2,32-35).

Considering the importance of $\mathrm{CO}$ poisoning and with regard to the promising properties of MS, in the present study, we examined the effects of MS on CO-induced cerebral injury in rats.

\section{Materials and methods}

Animals. In the present study, 25 male Wistar rats (8-10 weeks old; weight, 200-250 g), were obtained from the Animal House of Zabol University of Medical Sciences (Zabol, Iran). The animals were kept under standard conditions (at $25^{\circ} \mathrm{C}$ with a $12 \mathrm{~h} / 12 \mathrm{~h}$ light/dark cycle) and were allowed access to food and water ad libitum. The present study was approved by the Ethics Committee of Zabol University of Medical
Sciences (approval no. ZBMU.1.REC.1394.112). All animals were treated in accordance with the guidelines for the Care And Use Of Laboratory Animals prepared by the Animal Research Ethics Committee of Zabol University of Medical Sciences and in conformity with EU Directive 2010/63/EU for animal experiments. The animals were randomly divided into 5 groups namely, the intact group (rats that were not exposed to $\mathrm{CO}$ ), the control (rats that were exposed to $\mathrm{CO}$ and received normal saline) and $3 \mathrm{MS}$-treated groups (rats that were exposed to $\mathrm{CO}$ and received MS 75, 150 and $300 \mathrm{mg} / \mathrm{kg}$ ). CO poisoning was induced by exposing the animals to $\mathrm{CO}$ at 3,000 ppm for $60 \mathrm{~min}$, as previously described (36). Immediately following the exposure period, the first dose of MS (or normal saline for the control group) was administered intraperitoneally (i.p.) and the next 4 doses were administered on the next 4 consecutive days on a daily basis (a total of 5 doses of MS).

Chemicals. Protein kinase B (Akt; cat. no. 4685S; dilution, 1/1,000), Bcl2-associated-X (cat. no. 2772S; dilution, 1/1,000), Bcl2 (cat. no. 2876S; dilution, 1/1,000) and anti- $\beta$-actin (cat. no. 4967S; dilution, $1 / 1,000$ ) antibodies and secondary rabbit antibody (anti-rabbit IgG, HRP-linked; cat. no. 7074S) were all purchased from Cell Signaling Technology Inc. (Danvers, MA, USA). The Coomassie (Bradford) Protein Assay kit was purchased from Thermo Fisher Scientific, Inc. (Waltham, MA, USA). A CO capsule (99.999\% purity) was obtained from Darman Gas (Tehran, Iran). Thiobarbituric acid was obtained from Sigma-Aldrich; Merck KGaA (Darmstadt, Germany) and MS was purchased from Pasteur Institute (Tehran, Iran).

Study design and treatments. For $\mathrm{CO}$ poisoning induction, the rats were placed in a 12-liter airtight Plexiglas container which was connected via polyethylene glycol (PEG) tubes to oxygen and $\mathrm{CO}$ capsules. The $\mathrm{CO}$ concentration was continuously monitored by a CO analyzer (TPI 707 Carbon Monoxide Analyzer; TPI Korea Co., Anyang, Korea) and had a constant level of 3,000 $\pm 100 \mathrm{ppm}$ for $1 \mathrm{~h}$. Subsequently, the animals were exposed to ambient air and MS was injected (i.p.) at 3 doses $(75,150$ and $300 \mathrm{mg} / \mathrm{kg})$. On the 5 th day, at $2 \mathrm{~h}$ after the final injection, the animals were anesthetized by an intraperitoneal administration of ketamine $(90 \mathrm{mg} / \mathrm{kg})$ and xylazine $(10 \mathrm{mg} / \mathrm{kg})$ and sacrificed. The brain samples were then collected and harvested for further evaluation. Moreover, for western blot analysis and malondialdehyde (MDA) assay, the harvested samples were preserved in cryotubes and stored at $-80^{\circ} \mathrm{C}$, as previously described (37).

Carboxyhemoglobin level assessment. Within $30 \mathrm{~min}$ following exposure $\mathrm{CO}$, blood samples were obtained from the tail of the animals. The serum carboxyhemoglobin concentration was measured using a spectrophotometer calibrated for rat blood (Jenway 6305; Bibby Scientific Ltd., Staffordshire, $\mathrm{UK})$, to ensure the induction of $\mathrm{CO}$ poisoning (38).

Histopathological examinations. For histopathological evaluation, serial brain sections (5- $\mu$ m-thick; corresponding to bregma $-3.3 \mathrm{~cm}$ ) according to a histological atlas (39) were obtained. The samples were placed in microtubes containing $10 \%$ formalin for fixation and $24 \mathrm{~h}$ later, they were sent to the 

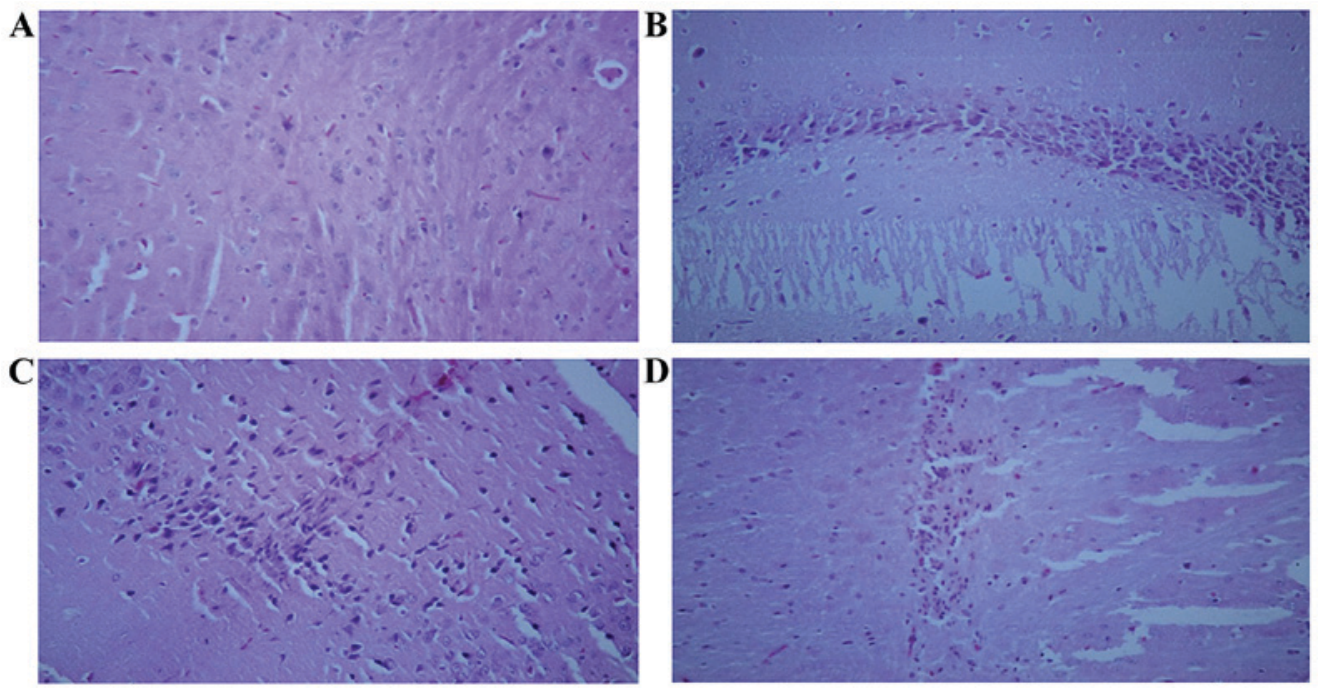

Figure 1. Representative images of (A) intact brain and histological insults observed in whole-brain samples following exposure to CO at 3,000 ppm, including (B) mild insults (dispersed necrotic cells and/or lymphatic infiltration), (C) moderate insults (bifocal necrotic areas) and (D) severe insults ( $>2$ necrotic foci) (magnification, $\mathrm{x} 40$ ). CO, carbon monoxide; MS, magnesium sulfate.

Pathology Department of Amiralmomenin Hospital (Zabol, Iran). Following H\&E staining, pathological insults were evaluated based on the severity of the injury, by a pathologist who was blinded to the grouping and treatments. The findings were categorized into 3 grades of mild (dispersed necrotic cells and/or lymphatic infiltration) (Fig. 1B), moderate (necrotic unifocal and/or bifocal area) (Fig. 1C), and severe (more than two necrotic areas) (Fig. 1D) insults.

Bax, Bcl2 and Akt protein expression assessment. For the determination of Akt, Bax, $\mathrm{Bcl} 2$ and $\beta$-actin expression, western blot analysis was performed. For this purpose, first, approximately $200 \mathrm{mg}$ of harvested whole brain samples which were kept at $-80^{\circ} \mathrm{C}$, were weighed, homogenized using a mechanical homogenizer, sonicated and centrifuged using a refrigerated centrifuge at $10,000 \mathrm{x} \mathrm{g}$ at $4^{\circ} \mathrm{C}$ for $10 \mathrm{~min}$. The supernatants were then collected, the protein contents were measured using the Coomassie (Bradford) Protein Assay kit which was purchased from Thermo Fisher Scientific, Inc. and samples were placed in a hot bath (boiling water) for the denaturation of proteins.

In order to determine the total $\mathrm{Akt}, \mathrm{Bax}, \mathrm{Bcl} 2$ and $\beta$-actin levels, 5-10 $\mu \mathrm{l}$ of supernatant was loaded into $12 \%$ SDS page wells and proteins were separated using gel electrophoresis (Bio-Rad power supply, $120 \mathrm{v}$ for $1.5 \mathrm{~h}$; Bio-Rad, Hercules, CA, USA). At the end of the electrophoresis period, proteins were transferred (Bio-Rad power supply, $350 \mathrm{~mA}, 25-45 \mathrm{~min}$; Bio-Rad) to a PVDF membrane using transfer buffer $(25 \mathrm{mM}$ Tris, $1.2 \mathrm{mM}$ glycine, and $20 \%$ methanol; $\mathrm{pH} 8.0$ ). The membrane was washed 3 times (each time for $5 \mathrm{~min}$ ) with Tris-buffered saline (TBS). After blocking in 5\% non-fat milk in TBST $(0.5 \%$ Tween-20, $137 \mathrm{mM} \mathrm{NaCl}, 20 \mathrm{mM}$ Tris- $\mathrm{HCl}$ $\mathrm{pH} 7.5$ ) overnight at $4^{\circ} \mathrm{C}$, the membranes were incubated with the primary antibodies for $1 \mathrm{~h}$ at room temperature on a rocker. The membrane was then washed 5 times (each time for $5 \mathrm{~min}$ ) in washing buffer, in order to remove any unbound conjugate proteins. The samples were then treated with the secondary antibody for $1 \mathrm{~h}$ at room temperature, washed thoroughly with
TBST and visualized by means of 500-1,000 $\mu 1$ of enhanced chemiluminescence (Pierce, Rockford, IL, USA) to visualize the blots using Syngene ChemiDoc (Syngene, Frederick, MD, USA). Eventually, blot analysis was carried out using GeneTools software.

Thiobarbituric acid reactive substances (TBARS) assay. MDA is a product of lipid peroxidation that can be measured by spectrophotometric methods $(40,41)$. In this study, the brain samples $(200 \mathrm{mg})$ were homogenized in cold $1.15 \%$ potassium chloride to yield a $10 \%$ homogenate. Subsequently, $0.5 \mathrm{ml}$ of the $10 \%$ homogenate was mixed with $3 \mathrm{ml}$ of phosphoric acid $1 \% \mathrm{w} / \mathrm{v}$, boiled for $45 \mathrm{~min}$ at $95^{\circ} \mathrm{C}$ and centrifuged at $12,000 \mathrm{x} \mathrm{g}$ for $10 \mathrm{~min}$. After cooling to room temperature, $4 \mathrm{ml} \mathrm{n}$-butanol was added and the reaction mixture was vortexed. The absorbance of the supernatant was measured at $532 \mathrm{~nm}$ (40) using a spectrophotometer (Jenway 6305; Bibby Scientific Ltd.) and the level of MDA was expressed as nmol per gram of wet tissue.

Statistical analysis. Data were analyzed using SPSS version 16 software (SPSS, Inc., Chicago, IL, USA). One-way analysis of variance followed by Tukey's post hoc test, was used for data analysis. $\mathrm{P}<0.05$ was considered to indicate a statistically significant difference.

\section{Results}

Carboxyhemoglobin concentration and the effect of MS on $\mathrm{CO}$-induced brain histological insults. The mean blood carboxyhemoglobin concentration was $70 \pm 8 \%$ in the CO-exposed rats. Brain histopathological evaluations revealed that MS treatment decreased the number and intensity of brain insults in the CO-poisoned rats. As shown in Fig. 1, brain samples were stained with $\mathrm{H} \& \mathrm{E}$ and brain insults were categorized as mild (dispersed necrotic cells and/or lymphocytic infiltration), moderate (necrotic cells with low foci) and severe (multi foci necrosis). As shown in Table I, in the control 
Table I. Histological findings in intact rats and in rats exposed to $\mathrm{CO}$ at 3,000 $\mathrm{ppm}$ for $1 \mathrm{~h}$ and treated with normal saline (control) and MS at 75, 150 and $300 \mathrm{mg} / \mathrm{kg}$.

\begin{tabular}{lcccc}
\hline Treatment & No injury & Mild & Moderate & Severe \\
\hline Intact & $5 / 5$ & $0 / 5$ & $0 / 5$ & $0 / 5$ \\
Normal saline & $0 / 5$ & $2 / 5$ & $1 / 5$ & $2 / 5$ \\
MS 75 mg/kg & $1 / 5$ & $1 / 5$ & $2 / 5$ & $1 / 5$ \\
MS $150 \mathrm{mg} / \mathrm{kg}$ & $3 / 5$ & $0 / 5$ & $1 / 5$ & $1 / 5$ \\
MS 300 mg/kg & $3 / 5$ & $1 / 5$ & $1 / 5$ & $0 / 5$ \\
\hline
\end{tabular}

${ }^{a} \mathrm{n} / \mathrm{m}$ ' indicates that ' $\mathrm{n}$ ' rats out of ' $\mathrm{m}$ ' rats (which is 5 in each group) had the specific grade of histopathological insults. CO, carbon monoxide; MS, magnesium sulfate.

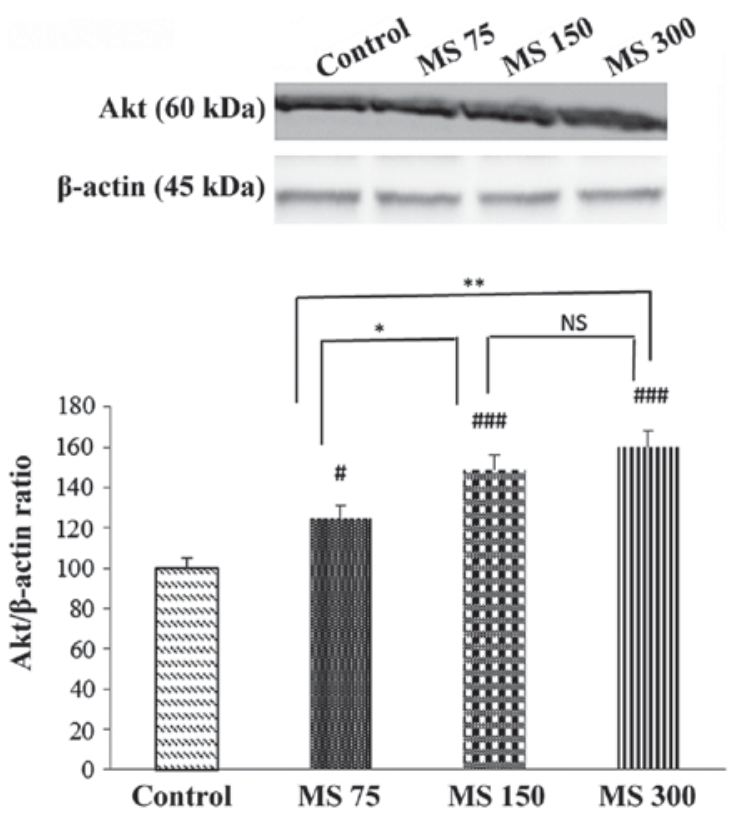

Figure 2. Effects of MS at 75, 150 and $300 \mathrm{mg} / \mathrm{kg}$ administered for 5 consecutive days, on Akt protein expression levels in CO-poisoned rats. Bars represent the means \pm SEM. ${ }^{~} \mathrm{P}<0.05$ and ${ }^{\# \# \#} \mathrm{P}<0.001$ indicate significant differences between the control and treatment groups. ${ }^{*} \mathrm{P}<0.05$ and ${ }^{* * *} \mathrm{P}<0.01$ indicate significant differences among the MS-treated groups. $\beta$-actin was used as the endogenous control. The control group rats were CO-poisoned animals treated with normal saline. NS, not significant. MS, magnesium sulfate; $\mathrm{CO}$, carbon monoxide.

group (normal saline-treated), 2 out of the 5 animals exhibited mild insults, 1 out of 5 had moderate insults and 2 out of 5 had severe insults, whereas in the group treated with MS at $300 \mathrm{mg} / \mathrm{kg}, 1$ out of 5 had mild and moderate insults and no animal showed severe insults. Furthermore, in the animals treated with MS at 75 and $150 \mathrm{mg} / \mathrm{kg}$, the number and severity of insults were decreased. Taken together, these results demonstrated that as compared to the control animals, all MS doses reduced $\mathrm{CO}$-induced damage to the brain tissues (Table I).

Effects of MS on Akt protein levels in CO-poisoned rats. As depicted in Fig. 2, the expression levels of Akt, as a pro-survival protein, significantly increased following treatment with MS as compared to the control group (normal saline-treated rats).

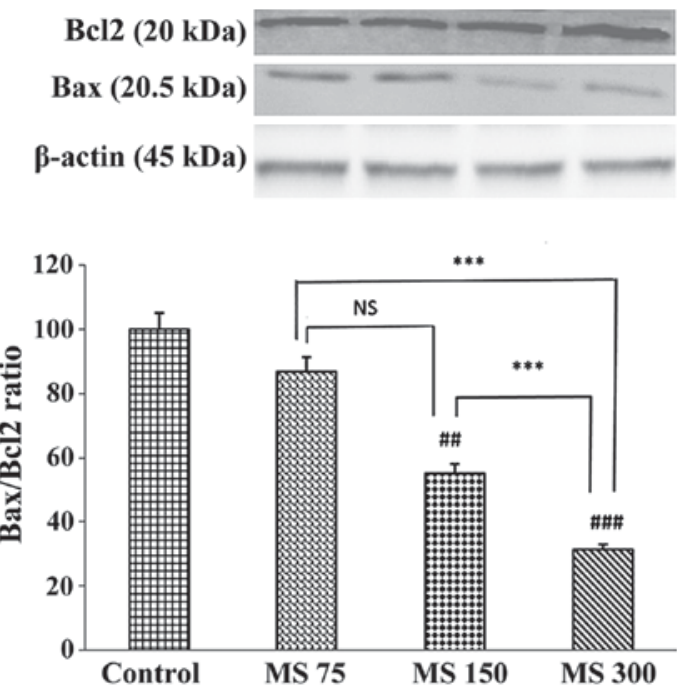

Figure 3. Effects of the 5-day administration of MS (75, 150 and $300 \mathrm{mg} / \mathrm{kg} / \mathrm{day}$ ) on $\mathrm{Bax} / \mathrm{Bcl} 2$ proteins ratio in the brains of rats. Bars represent the means \pm SEM values. All groups were compared to the normal saline-treated control group (one-way analysis of variance followed by Tukey's post-hoc test was used for statistical analysis). ${ }^{* * *} \mathrm{P}<0.001$ indicates statistically significant differences among the MS-treated groups. ${ }^{\# \#} \mathrm{P}<0.01$ and ${ }^{\# \# \#} \mathrm{P}<0.001$ indicate significant differences between the control and MS-treated groups. $\beta$-actin was used as the endogenous control. The control group rats were $\mathrm{CO}$-poisoned animals treated with normal saline. NS, not significant; MS, magnesium sulfate; $\mathrm{CO}$, carbon monoxide; $\mathrm{Bcl} 2$, B-cell lymphoma-2; Bax, Bcl2-associated-X protein.

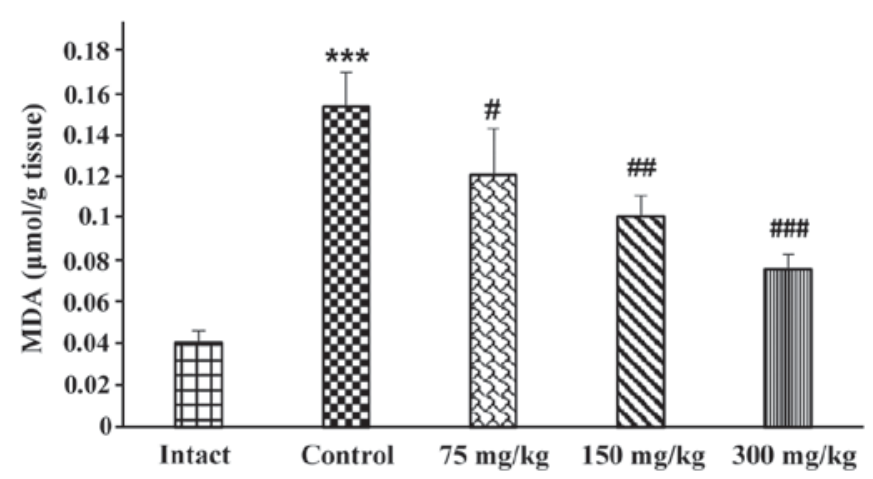

Figure 4. Effect of 5-day MS administration on MDA levels in CO-poisoned rats. Results are expressed as the means \pm SEM of each group. ${ }^{* * *} \mathrm{P}<0.001$ indicates significant difference between the intact and control group. ${ }^{\#} \mathrm{P}<0.05$, ${ }^{\# \#} \mathrm{P}<0.01$ and ${ }^{\# \#} \mathrm{P}<0.001$ indicate significant differences between the control and treatment groups. The control group rats were $\mathrm{CO}$-poisoned animals treated with normal saline. MS, magnesium sulfate; $\mathrm{CO}$, carbon monoxide; MDA, malondialdehyde.

In addition, significant differences were observed between the MS 300 and MS $75(\mathrm{P}<0.01)$, and between the MS 150 and MS $75(\mathrm{P}<0.05)$ groups. Furthermore, the differences between MS treatment at 150 and $300 \mathrm{mg}$ and the control groups were significant (for both cases $\mathrm{P}<0.001$ ).

Effect of MS on Bax/Bcl2 protein ratio in brain cells following treatment with $M S$ in $C O$-poisoned rats. Compared to the control group, in the MS treatment groups, Bax protein expression levels were decreased, while Bcl2 (an anti-apoptotic protein) expression levels were increased (Fig. 3). It was evident 


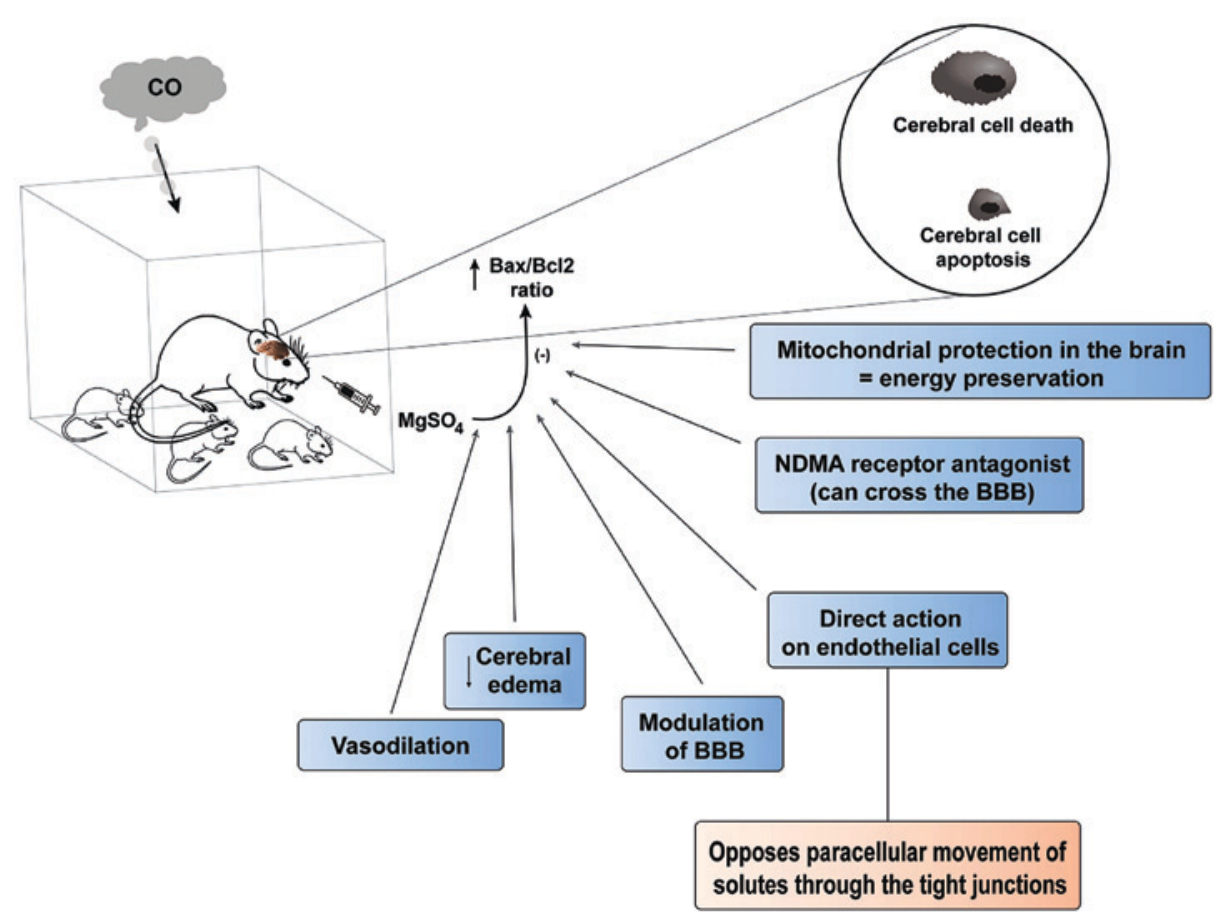

Figure 5. A schematic presentation of the present study along with the underlying mechanisms suggested for the neuroprotective effects of magnesium sulfate (61-65). $\mathrm{MgSO}^{4}$, magnesium sulfate; NDMA, $\mathrm{N}$-ditrosodimethylamine; $\mathrm{BBB}$, blood-brain barrier; $\mathrm{CO}$, carbon monoxide; Bcl2, B-cell lymphoma-2; Bax, Bcl2-associated-X protein.

that following treatment with MS at 150 and $300 \mathrm{mg} / \mathrm{kg}$, the $\mathrm{Bax} / \mathrm{Bcl} 2$ ratio was decreased in comparison to the control group $(\mathrm{P}<0.01$ and $\mathrm{P}<0.001$, respectively). Based on our data, MS was able to decrease the $\mathrm{Bax} / \mathrm{Bcl} 2$ apoptotic index in brain cells following $\mathrm{CO}$ poisoning.

TBARS assay. The present study demonstrated that oxidative stress was increased following $\mathrm{CO}$ poisoning compared to the control $(\mathrm{P}<0.001)$. MS treatment $(75,150$ and $300 \mathrm{mg} / \mathrm{kg})$ dose-dependently decreased the oxidative stress levels in rats in comparison to the control group $(\mathrm{P}<0.05, \mathrm{P}<0.01$ and $\mathrm{P}<0.001$, respectively) (Fig. 4).

\section{Discussion}

The neuro-protective properties of MS make it a potential candidate for the alleviation of the deleterious effects of cerebral I/R injury (17). Since CO induces damage by inducing hypoxia, tissues with a greater $\mathrm{O}_{2}$ consumption, including the heart and brain, are more vulnerable to the effects of $\mathrm{CO}$ poisoning $(9,42)$. CO poisoning intensity depends on a number of factors, including $\mathrm{CO}$ levels during exposure and the exposure period (9). Furthermore, $\mathrm{CO}$ poisoning has acute and delayed consequences $(1,39,43)$. In the current study, we demonstrated that MS decreased brain cell necrosis, apoptosis and oxidative stress, while it increased pro-survival Akt protein levels in a dose-dependent manner. Previously, we reported several neuroprotective and cardioprotective substances, which may be used to decrease $\mathrm{CO}$ poisoning consequences, in animal models (2,33,36,37,42,44-46). More specifically, in a recent study from our group, MS administration was found to exert positive effects against the cardiotoxicity of $\mathrm{CO}$ in rats (33). Magnesium dilates blood vessels and lowers the heart rate. However, the early administration of magnesium in high-risk patients has been shown to have no effect on mortality (47).

Moreover, $\mathrm{CO}$ poisoning induces cerebral hypoxia that may lead to infarction and necrosis (9). In previous studies, the potent effects of MS in decreasing the infarct size in animal models were observed $(14,17)$. Marinov et al demonstrated that the intra-arterial administration of a single dose of MS 90 $\mathrm{mg} / \mathrm{kg}$ reduced the cerebral infarct size in animals submitted to reversible middle cerebral artery occlusion (17). Consistent with this, the results of this study revealed that MS (at 75, 150 and $300 \mathrm{mg} / \mathrm{kg}$ ) decreased the number and intensity of cerebral insults in a dose-dependent manner in an animal model of $\mathrm{CO}$ poisoning.

It is known that Akt protein plays a key role in cell survival by inhibiting apoptosis (48). Mechanistically, PI3kinase/Akt (also known as protein kinase B) pathway activation is considered neuroprotective in the case of cerebral I/R (48-50). In the present study, it was found that MS increased brain Akt protein expression levels and decreased apoptosis in the context of $\mathrm{CO}$ poisoning. This finding is consistent with the observations of Yu et al, indicating that the PI3kinase/Akt pathway activation is critically important for brain cell survival in case of cerebral ischemia through decreasing apoptosis (50).

In addition, the present study demonstrated that MS treatment decreased the $\mathrm{Bax} / \mathrm{Bcl} 2$ ratio, an apoptotic index, in brain tissues post- $\mathrm{CO}$ poisoning. Bax is a mitochondrial pro-apoptotic protein, the expression of which increases during the activation of the intrinsic apoptotic pathway and leads to mitochondrial injury (51). At the same time, $\mathrm{Bcl} 2$ is an anti-apoptotic protein which is produced in order to counteract pro-apoptotic signals and protect from mitochondrial injuries (52). The $\mathrm{Bax} / \mathrm{Bcl} 2$ ratio is considered a measure of cell 
susceptibility to apoptosis (53) and in the current study, this ratio was found to be significantly decreased following MS administration in a dose-dependent manner. Ravishankar et al demonstrated that cerebral ischemia increased apoptosis via increasing pro-apoptotic Bax and decreasing anti-apoptotic $\mathrm{Bcl} 2$ expression in an animal model of cerebral hypoxia (54). The results of this study are in agreement with the data reported by several previous studies on MS effects in animal models of cerebral I/R injury and clinical studies on global cerebral ischemia associated with cardiac arrest and cardiac surgery which showed MS neuro-protective and cerebral anti-apoptotic properties $(15,21,55)$.

Oxidative stress is able to damage cell components (e.g., proteins, DNA and lipids) and organelles (56) and has been shown to be related with various pathological conditions $(57,58)$; increased oxidative stress leads to neuronal death by damaging brain cellular lipids, proteins and nucleic acids and induces apoptosis through the transcription of the pro-apoptotic BID and BAD factors (59). Yavuz et al demonstrated that a single dose of MS reduced brain oxidative stress following $\mathrm{CO}$ poisoning and that the intraperitoneal administration of MS at $100 \mathrm{mg} / \mathrm{kg}$ was sufficient to significantly decrease lipid peroxidation (60). The findings of this study (for a brief summary, see Fig. 5) are in agreement with that study as MS treatment reduced lipid peroxidation at all 3 doses $(75,150$ and $300 \mathrm{mg} / \mathrm{kg}$ ) and proved that lipid peroxidation co-exists with apoptotic induction in $\mathrm{CO}$ poisoning and that brain cell Akt pathway activation favorably modulates the $\mathrm{Bax} / \mathrm{Bcl} 2$ apoptotic index downstream (60).

In conclusion, the current study demonstrated that MS administration decreased the deleterious effects of $\mathrm{CO}$ poisoning on the brain by decreasing neuronal necrosis and apoptosis and reducing oxidative stress, while increasing Akt expression in brain cells.

\section{Acknowledgements}

The authors would like to thank the Pathology Laboratories of Amiralmomenin Hospital (Zabol University of Medical Sciences) for their kind assistance.

\section{Funding}

The present study was part of a Pharm. D. funded by Zabol University of Medical Sciences and Students Research Committee of Zabol University of Medical Sciences.

\section{Availability of data and materials}

All data generated or analyzed during this study are included in this published article.

\section{Authors' contributions}

GB and RR and $\mathrm{MH}$ conceived and designed, and supervised the study. JS, MS, KTa and SB collected and analyzed the data. HJ performed the histopothological analysis. KTs, AOD, AAM, MFW, AT and DAS interpreted the data and prepared the manuscript. All authors have read and approved the final version of the manuscript.

\section{Ethics approval and consent to participate}

The present study was approved by the Ethics Committee of Zabol University of Medical Sciences, Zabol, Iran (approval no. ZBMU.1.REC.1394.112). All the animals were treated in accordance with the guidelines for care and use of laboratory animals prepared by the Animal Research Ethics Committee of Zabol University of Medical Sciences and in conformity with EU Directive 2010/63/EU for animal experiments.

\section{Patient consent for publication}

Not applicable.

\section{Competing interests}

DAS is the Editor-in-Chief for the journal, but had no personal involvement in the reviewing process, or any influence in terms of adjudicating on the final decision, for this article. All the remaining authors have no competing interests to disclose.

\section{References}

1. Weaver LK, Hopkins RO, Chan KJ, Churchill S, Elliott CG, Clemmer TP, Orme JF Jr, Thomas FO and Morris AH: Hyperbaric oxygen for acute carbon monoxide poisoning. N Engl J Med 347: 1057-1067, 2002.

2. Tabrizian K, Shahraki J, Bazzi M, Rezaee R, Jahantigh H and Hashemzaei M: Neuro-Protective Effects of Resveratrol on Carbon Monoxide-Induced Toxicity in Male Rats. Phytother Res 31: 1310-1315, 2017.

3. Rose JJ, Wang L, Xu Q, McTiernan CF, Shiva S, Tejero J and Gladwin MT: Carbon monoxide poisoning: Pathogenesis, management, and future directions of therapy. Am J Respir Crit Care Med 195: 596-606, 2017.

4. Shahsavand S, Mohammadpour AH, Rezaee R, Behravan E, Sakhtianchi R and Moallem SA: Effect of erythropoietin on serum brain-derived biomarkers after carbon monoxide poisoning in rats. Iran J Basic Med Sci 15: 752-758, 2012.

5. Hampson NB: Cost of accidental carbon monoxide poisoning: A preventable expense. Prev Med Rep 3: 21-24, 2015.

6. Khadem-Rezaiyan M and Afshari R: Carbon monoxide poisoning in Northeast of Iran. J Forensic Leg Med 41: 1-4, 2016.

7. Ghorani-Azam A, Riahi-Zanjani B and Balali-Mood M: Effects of air pollution on human health and practical measures for prevention in Iran. J Res Med Sci 21: 65, 2016.

8. Mirahmadizadeh A, Faramarzi H, Hadizadeh E, Moghadami M, Fardid $\mathrm{M}$ and Seifi A: A yearlong epidemiologic study on unintentional acute carbon monoxide poisoning in Fars province, Southwest Iran. Asia Pac J Med Toxicol 5: 15-19, 2016.

9. Winter PM and Miller JN: Carbon monoxide poisoning. JAMA 236: 1502-1504, 1976.

10. Ghosh A, Banerjee S, Mitra A, Muralidharan M, Roy B, Banerjee R, Mandal AK and Chatterjee IB: Interaction of p-benzoquinone with hemoglobin in smoker's blood causes alteration of structure and loss of oxygen binding capacity. Toxicol Rep 3: 295-305, 2016.

11. Smollin $\mathrm{C}$ and Olson K: Carbon monoxide poisoning (acute). BMJ Clin Evid: 12 Oct, pii: 2103, 2010.

12. Vargas R and Ponce-Canchihuamán J: Emerging various environmental threats to brain and overview of surveillance system with zebrafish model. Toxicol Rep 4: 467-473, 2017.

13. Hashemzaei AM, Keykha BS, Shahraki CF, Mohammadpour DA and Tabrizian EK: Effects of magnesium sulfate on the acquisition and reinstatement of morphine-induced conditioned place preference in mice. J Fundam Appl Sci 8: 112-123, 2016.

14. Lin JY, Chung SY, Lin MC and Cheng FC: Effects of magnesium sulfate on energy metabolites and glutamate in the cortex during focal cerebral ischemia and reperfusion in the gerbil monitored by a dual-probe microdialysis technique. Life Sci 71: 803-811, 2002. 
15. Pearce A, Lockwood C, van den Heuvel C and Pearce J: The use of therapeutic magnesium for neuroprotection during global cerebral ischemia associated with cardiac arrest and cardiac surgery in adults: A systematic review. JBI Database Syst Rev Implement Reports 15: 86-118, 2017.

16. Zhao L, Wang W, Zhong J, Li Y, Cheng Y, Su Z, Zheng W and Guan XD: The effects of magnesium sulfate therapy after severe diffuse axonal injury. Ther Clin Risk Manag 12: 1481-1486, 2016.

17. Marinov MB, Harbaugh KS, Hoopes PJ, Pikus HJ and Harbaugh RE: Neuroprotective effects of preischemia intraarterial magnesium sulfate in reversible focal cerebral ischemia. $\mathrm{J}$ Neurosurg 85: 117-124, 1996.

18. Muir KW: Magnesium for neuroprotection in ischaemic stroke: Rationale for use and evidence of effectiveness. CNS Drugs 15: 921-930, 2001.

19. O'Collins VE, Macleod MR, Donnan GA, Horky LL, van der Worp BH and Howells DW: 1,026 experimental treatments in acute stroke. Ann Neurol 59: 467-477, 2006.

20. Yang Y, Li Q, Ahmad F and Shuaib A: Survival and histological evaluation of therapeutic window of post-ischemia treatment with magnesium sulfate in embolic stroke model of rat. Neurosci Lett 285: 119-122, 2000.

21. Zhou H, Ma Y, Zhou Y, Liu Z, Wang K and Chen G: Effects of magnesium sulfate on neuron apoptosis and expression of caspase-3, bax and bcl-2 after cerebral ischemia-reperfusion injury. Chin Med J (Engl) 116: 1532-1534, 2003.

22. Dubé L and Granry JC: The therapeutic use of magnesium in anesthesiology, intensive care and emergency medicine: a review. Can J Anaesth 50: 732-746, 2003.

23. Karimani A, Mohammadpour AH, Zirak MR, Rezaee R, Megarbane B, Tsatsakis A and Karimi G: Antidotes for aluminum phosphide poisoning - An update. Toxicol Rep 5: $1053-1059,2018$

24. Xu X, Zhang H, Wang $\mathrm{K}, \mathrm{Tu} \mathrm{T}$ and Jiang Y: Protective effect of edaravone against carbon monoxide induced apoptosis in rat primary cultured astrocytes. Biochem Res Intern: doi. org/10.1155/2017/5839762.

25. Song S, Jacobson KN, McDermott KM, Reddy SP, Cress AE, Tang H, Dudek SM, Black SM, Garcia JG, Makino A and Yuan JXJ: ATP promotes cell survival via regulation of cytosolic $\left[\mathrm{Ca}^{2+}\right]$ and $\mathrm{Bcl}-2 /$ Bax ratio in lung cancer cells. Am J Physiol Cell Physiol 310: C99-C114, 2016.

26. Zhang B, Liu Y, Li Y, Zhe X, Zhang S and Zhang L: Neuroglobin promotes the proliferation and suppresses the apoptosis of glioma cells by activating the PI3K/AKT pathway. Mol Med Rep 17: 2757-2763, 2018.

27. Wang F, Li H and Qiao JO: $1 \mathrm{O}$ acetylbritannilactone combined with gemcitabine elicits growth inhibition and apoptosis in A549 human non small cell lung cancer cells. Mol Med Rep 12: $5568-5572,2015$.

28. Hashemzaei M, Delarami Far A, Yari A, Heravi RE, Tabrizian K, Taghdisi SM, Sadegh SE, Tsarouhas K, Kouretas D, Tzanakakis G, et al: Anticancer and apoptosis inducing effects of quercetin in vitro and in vivo. Oncol Rep 38: 819-828, 2017.

29. Rezaee MA, Mohammadpour AH,Imenshahidi M, Mahmoudi M, Sankian M, Tsarouhas K, Tsakalof A, Tsatsakis AM and Moallem SA: Protective effect of erythropoietin on myocardial apoptosis in rats exposed to carbon monoxide. Life Sci 148 : 118-124, 2016

30. Wang Y, Li Y, Song L, Li Y, Jiang S and Zhang S: The transplantation of Akt-overexpressing amniotic fluid-derived mesenchyma stem cells protects the heart against ischemia-reperfusion injury in rabbits. Mol Med Rep 14: 234-242, 2016.

31. Yang P, Zhao J, Hou L, Yang L, Wu K and Zhang L: Vitamin E succinate induces apoptosis via the PI3K/AKT signaling pathways in EC109 esophageal cancer cells. Mol Med Rep 14: $1531-1537,2016$.

32. Luan Q, Pan L, He D, Gong X and Zhou H: SC79, the AKT Activator Protects Cerebral Ischemia in a Rat Model of Ischemia/Reperfusion Injury. Med Sci Monit 24: 5391-5397, 2018.

33. Tabrizian K, Khodayari H, Rezaee R, Jahantigh H, Bagheri G, Tsarouhas K and Hashemzaei M: Magnesium sulfate protects the heart against carbon monoxide-induced cardiotoxicity in rats. Res Pharm Sci 13: 65-72, 2018.

34. Huang C, Guo X, Zhao H, An R, Lian K, Zhang X, Zhang J, Yan F, Xie H, Wang S and Tao L: Nicotine induces H9C2 cell apoptosis via Akt protein degradation. Mol Med Rep 16: 6269-6275, 2017.
35. Kashafi E, Moradzadeh M, Mohamadkhani A and Erfanian S: Kaempferol increases apoptosis in human cervical cancer HeLa cells via PI3K/AKT and telomerase pathways. Biomed Pharmacother 89: 573-577, 2017.

36. Hashemzaei M, Barani AK, Iranshahi M, Rezaee R, Tsarouhas $K$, Tsatsakis AM, Wilks MF and Tabrizian K: Effects of resveratrol on carbon monoxide-induced cardiotoxicity in rats. Environ Toxicol Pharmacol 46: 110-115, 2016.

37. Mohamadpour AH, Moallem SA, Hashemzaei M, Abnous K, Tabatabaee Yazdi SA and Imenshahidi M: Effects of granulocyte colony-stimulating factor on electrocardiogram changes after carbon monoxide poisoning in rats. Drug Chem Toxicol 35: 353-360, 2012

38. Rodkey FL, Hill TA, Pitts LL and Robertson RF: Spectrophotometric measurement of carboxyhemoglobin and methemoglobin in blood. Clin Chem 25: 1388-1393, 1979.

39. Moallem SA, Mohamadpour AH, Abnous K, Sankian M, Sadeghnia HR, Tsatsakis A and Shahsavand S: Erythropoietin in the treatment of carbon monoxide neurotoxicity in rat. Food Chem Toxicol 86: 56-64, 2015.

40. Draper HH and Hadley M: Malondialdehyde determination as index of lipid peroxidation. Methods Enzymol 186: 421-431, 1990.

41. Hasanzadeh D, Mahdavi M, Dehghan G and Charoudeh HN: Farnesiferol $\mathrm{C}$ induces cell cycle arrest and apoptosis mediated by oxidative stress in MCF-7 cell line. Toxicol Rep 4: 420-426, 2017.

42. Ghorbani M, Mohammadpour AH, Abnous K, Movassaghi AR, Sarshoori JR, Shahsavand S, Hashemzaei M, Moallem SA $\mathrm{G}-\mathrm{CSF}$ administration attenuates brain injury in rats following carbon monoxide poisoning via different mechanisms. Environ Toxicol 32: 37-47, 2017.

43. Guzman JA: Carbon monoxide poisoning. Crit Care Clin 28: 537-548, 2012

44. Hashemzaei M, Imen Shahidi M, Moallem SA, Abnous K, Ghorbani $\mathrm{M}$ and Mohamadpour AH: Modulation of JAK2, STAT3 and Akt1 proteins by granulocyte colony stimulating factor following carbon monoxide poisoning in male rat. Drug Chem Toxicol 39: 375-379, 2016.

45. Tabrizian K, Shahriari Z, Rezaee R, Jahantigh H, Bagheri G, Tsarouhas K, Docea AO, Tsatsakis A and Hashemzaei M: Cardioprotective effects of insulin on carbon monoxide-induced toxicity in male rats. Hum Exp Toxicol: Jan 1, 2018. doi:10.1177/0960327118788134

46. Hashemzaei M, Mohammadpour AH, Imenshahidi M, Rezaee R and Moallem SA: Does granulocyte colony stimulating factor have protective effects against carbon monoxide-induced apoptosis? Biologia 73: 1153-1157, 2018.

47. Antman EM: Early administration of intravenous magnesium to high-risk patients with acute myocardial infarction in the Magnesium in Coronaries (MAGIC) Trial: A randomised controlled trial. The Lancet 360: 1189-1196, 2002.

48. Zhang H, Xiong X, Liu J, Gu L, Li F, Wan Y and Xu S: Emulsified Isoflurane Protects Against Transient Focal Cerebral Ischemia Injury in Rats via the PI3K/Akt Signaling Pathway. Anesth Analg 122: 1377-1384, 2016.

49. Wen X-R, Fu Y-Y, Liu H-Z, Wu J, Shao XP, Zhang XB, Tang M, Shi Y, Ma K, Zhang F, et al: Neuroprotection of sevoflurane against Ischemia/Reperfusion-induced brain injury through inhibiting JNK3/Caspase-3 by enhancing Akt signaling pathway. Mol Neurobiol 53: 1661-1671, 2016.

50. Yu Z-H, Cai M, Xiang J, Zhang ZN, Zhang JS, Song XL, Zhang W, Bao J, Li WW and Cai DF: PI3K/Akt pathway contributes to neuroprotective effect of Tongxinluo against focal cerebral ischemia and reperfusion injury in rats. J Ethnopharmacol 181: 8-19, 2016.

51. Scorrano L, Oakes SA, Opferman JT, Cheng EH, Sorcinelli MD, Pozzan T and Korsmeyer SJ: BAX and BAK regulation of endoplasmic reticulum $\mathrm{Ca}^{2+}$ : A control point for apoptosis. Science 300: 135-139, 2003

52. Edlich F and Martinou JC: Bcl-2 protein interplay on the outer mitochondrial membrane. In: Mitochondria and Cell Death. Hockenbery DM (ed). Springer Sci Bus Med, New York, NY, pp 69-83, 2016.

53. Raisova M, Hossini AM, Eberle J, Riebeling C, Wieder T, Sturm I, Daniel PT, Orfanos CE and Geilen CC: The Bax/Bcl-2 ratio determines the susceptibility of human melanoma cells to CD95/Fas-mediated apoptosis. J Invest Dermatol 117: 333-340, 2001. 
54. Ravishankar S, Ashraf QM, Fritz K, Mishra OP and Delivoria-Papadopoulos M: Expression of Bax and Bcl-2 proteins during hypoxia in cerebral cortical neuronal nuclei of newborn piglets: Effect of administration of magnesium sulfate. Brain Res 901: 23-29, 2001.

55. Chamorro Á, Dirnagl U, Urra X and Planas AM: Neuroprotection in acute stroke: Targeting excitotoxicity, oxidative and nitrosative stress, and inflammation. Lancet Neurol 15: 869-881, 2016.

56. Rezaee R, Behravan E, Behravan J, Soltani F, Naderi Y, Emami B and Iranshahi M: Antigenotoxic activities of the natural dietary coumarins umbelliferone, herniarin and 7-isopentenyloxy coumarin on human lymphocytes exposed to oxidative stress. Drug Chem Toxicol 37: 144-148, 2014.

57. Yaribeygi H, Mohammadi MT, Rezaee R and Sahebkar A Crocin improves renal function by declining Nox-4, IL-18, and p53 expression levels in an experimental model of diabetic nephropathy. J Cell Biochem 119: 6080-6093, 2018.

58. Yaribeygi H, Mohammadi MT, Rezaee R and Sahebkar A: Fenofibrate improves renal function by amelioration of NOX-4, IL-18, and p53 expression in an experimental model of diabetic nephropathy. J Cell Biochem 119: 7458-7469, 2018.

59. Mattson MP: Apoptosis in neurodegenerative disorders. Nat Rev Mol Cell Biol 1: 120-129, 2000.

60. Yavuz Y, Mollaoglu H, Yürümez Y, Ucok K, Duran L, Tünay K and Akgün L: Therapeutic effect of magnesium sulphate on carbon monoxide toxicity-mediated brain lipid peroxidation. Eur Rev Med Pharmacol Sci 17 (Suppl 1): 28-33, 2013.

61. Koning G, Leverin A-L, Nair S, Schwendimann L, Ek J, Carlsson Y, Gressens P, Thornton C, Wang X, Mallard C and Hagberg H: Magnesium induces preconditioning of the neonatal brain via profound mitochondrial protection. J Cereb Blood Flow Metab: 1 Jan, 2017. (Epub ahead of print). https://doi. org/10.1177/0271678X17746132.
62. Kaya M, Gulturk S, Elmas I, Kalayci R, Arican N, Kocyildiz ZC, Kucuk M, Yorulmaz H and Sivas A: The effects of magnesium sulfate on blood-brain barrier disruption caused by intracarotid injection of hyperosmolar mannitol in rats. Life Sci 76: 201-212, 2004.

63. Ravn HB, Vissinger H, Kristensen SD, Wennmalm A, Thygesen K and Husted SE: Magnesium inhibits platelet activity--an infusion study in healthy volunteers. Thromb Haemost 75: 939-944, 1996.

64. Watson KV, Moldow CF, Ogburn PL and Jacob HS: Magnesium sulfate: Rationale for its use in preeclampsia. Proc Natl Acad Sci USA 83: 1075-1078, 1986.

65. Altura BM, Altura BT, Carella A, Gebrewold A, Murakawa T and Nishio A: $\mathrm{Mg}^{2+}-\mathrm{Ca}^{2+}$ interaction in contractility of vascular smooth muscle: $\mathrm{Mg}^{2+}$ versus organic calcium channel blockers on myogenic tone and agonist-induced responsiveness of blood vessels. Can J Physiol Pharmacol 65: 729-745, 1987.

This work is licensed under a Creative Commons Attribution-NonCommercial-NoDerivatives 4.0 International (CC BY-NC-ND 4.0) License. 